\title{
Lipids in suspended matter from the human-disturbed Lanyang River, northeastern Taiwan
}

Woei-Lih Jeng · Shuh-Ji Kao

Abstract Due to anthropogenic disturbance such as mass road construction, the sediment yield in the Lanyang River, northeastern Taiwan has been reported to have increased substantially since 1976 . Water samples were collected from the river on three occasions, and total suspended matter (TSM) was analyzed for aliphatic hydrocarbons and alkanols/ sterols. Results show that the distribution of aliphatic hydrocarbons in the TSM is rather complicated during periods of normal flow, but is relatively simple during high flow and after a period of an extraordinarily high, daily mean discharge. Carbon preference index (CPI) values of $n$-alkanes $\left(\mathrm{C}_{25}-\mathrm{C}_{33}\right)$ are comparatively low, ranging from 1.14 to 2.35 , with an average of 1.62, when compared with a control station ( $\mathrm{CPI}=5.88)$. Because there has been no anthropogenic fossil-fuel contamination in the study area in the past, the present results indicate a predominant hydrocarbon contribution from the old lipids derived from the bedrock (argillite-slate and meta-sandstone) due to massive road construction in 1975-1980, with a small contribution from modern vegetation. By using a two-end-member assumption, the percentage of old hydrocarbons in the TSM was estimated to be about $87 \%$. The presence of a $\mathrm{C}_{22} n$-alkanol maximum is attributed mainly to bacterial contribution. Higher plants are considered a major source of the campesterol, stigmasterol, and sitosterol in the TSM.

Received: 28 February 2002 / Accepted: 13 May 2002 Published online: 22 June 2002

(C) Springer-Verlag 2002

\footnotetext{
W.-L. Jeng ( $\square)$

Institute of Oceanography,

National Taiwan University, Taipei, Taiwan, ROC

E-mail: wljeng@oc.ntu.edu.tw

Tel.: +886-2-23636040 ext 301

Fax: $+886-2-23626092$

S.-J. Kao

Institute of Earth Sciences, Academia Sinica,

Taipei, Taiwan, ROC
}

Keywords Suspended matter Hydrocarbons . Lanyang River $\cdot$ Northeastern Taiwan

\section{Introduction}

The Lanyang River is a typical, small mountainous river in subtropical northeastern Taiwan, which is isolated from the rest of Taiwan by high mountains (Fig. 1). The river originates at 3,535 m above sea level, with a mean gradient of $1 / 21$ in the main stem, and it has a drainage area of $980 \mathrm{~km}^{2}$ and a length of $70 \mathrm{~km}$. The basement rock is composed mainly of Tertiary argillite-slate and metasandstone (Ho 1975). The main channel follows a strikeslip fault in the SW-NE direction (Ho 1982). North of the fault, the rock types are meta-sandstone and argillite; to the south, the rocks are argillite, phyllite, and slate. The geology is fairly uniform. The Lanyang alluvial fan is characterized by a small fan area, high elevation, steep slope, multisteps and deep dissection, reflecting the geomorphic environment of rapid uplift and significant erosion and deposition (Chang 1997).

The study area has a humid climate. More than $80 \%$ of the drainage area has a mean annual rainfall of 2,500-4,000 mm which results in luxuriant vegetation. On average, $38 \%$ of the runoff is derived from summer rain related to typhoons, and $41 \%$ is from precipitation during the northeast monsoon from September to April. Over 70\% of the rainfall in the Lanyang River watershed turns into surface runoff, and the denudation rate is rather high, like other watersheds of Taiwan (Li 1976). There is no dam on the whole river. The river discharges its sediment load of ca. $8 \times 10^{6}$ tons/year (Water Resources Bureau 1999) directly into the southern Okinawa Trough. A branch of the Central Cross-Island Highway constructed during 1957-1960, and a massive country-road construction during 1975-1980 are the two major anthropogenic disturbances in the watershed (Anon 1974, 1983). The increasing anthropogenic perturbations may also aggravate the erosion rate in the watershed, as indicated by Kao and Liu (1996). The mean total suspended matter (TSM) and particulate organic carbon (POC) yields of the whole drainage area are high $-3,600$ and $23 \mathrm{~g} \mathrm{~m}^{-2}$ year $^{-1}$, respectively (Kao and Liu 1996).

Rivers on western Taiwan have generally been polluted to various degrees by heavy metals (Hung and others 1990) and 


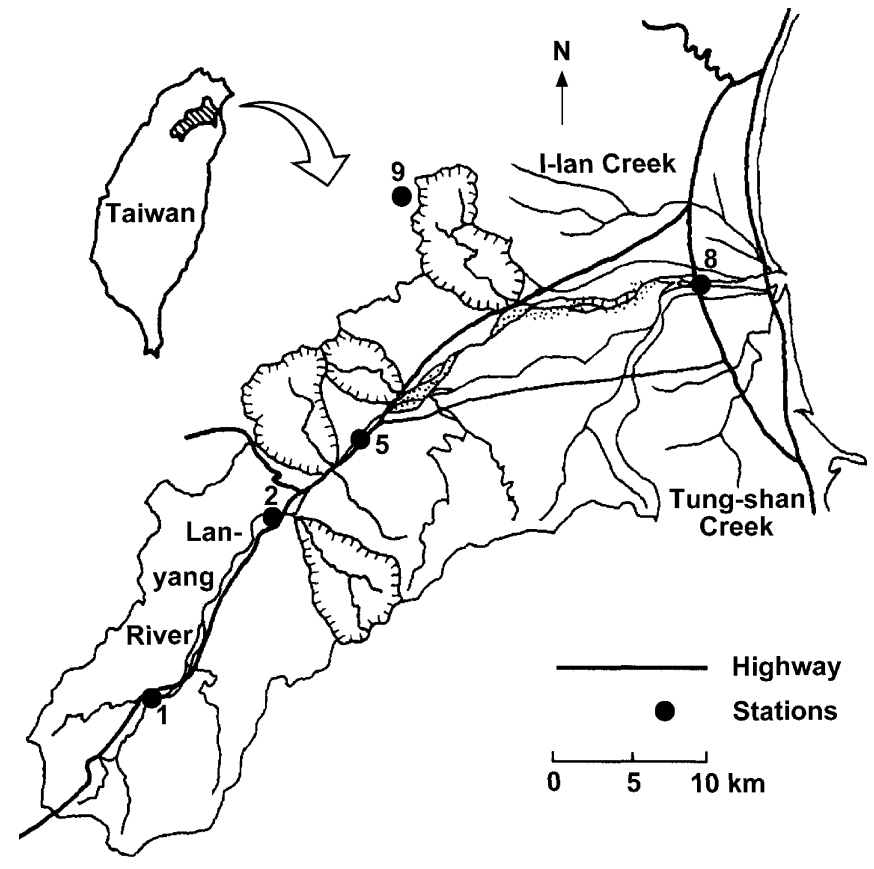

Fig. 1

Map of sampling locations along the Lanyang River. Four stations along the main channel, together with one station (\#9) located in an adjacent watershed within a nature reserve, were sampled. Two tributaries - I-lan Creek and Tung-shan Creek - near the river mouth were not included in this study

organic compounds (Jeng and Han 1994). However, the Lanyang River is an uncontaminated river with respect to heavy metals and fossil fuels in alpine Taiwan. There has been no study of lipids in suspended matter related to anthropogenic disturbance in the watershed of the study area. In this study, aliphatic hydrocarbons along with alkanols and sterols in river suspended matter were examined in order to understand the influence of human disturbance.

\section{Materials and methods}

Sampling sites were chosen to represent the whole Lanyang River (Fig. 1). Water samples were collected on three occasions: on 6 and 29 April 2000, during which time flows were normal and the water was a little turbid due to rain, and on 13 October 1998 when there was a high daily mean discharge. At each station, sampling was carried out from the center of a bridge over the river. Water samples were stored in 1-1 fluorinated HDPE bottles (Nalgene, NY, USA). Each water sample was passed through Whatman GF/F glass-fiber filters $(0.7-\mu \mathrm{m}$ retention size) which had been pre-extracted with acetone and methanol. Wet TSM-laden filters were freeze-dried. After adding internal standards $\left(n-\mathrm{C}_{24} \mathrm{D}_{50}\right.$ and 1-heptadecanol), dried TSM samples were extracted with a mixture of dichloromethane and methanol $(1: 1, v / v)$ for $24 \mathrm{~h}$ in a Soxhlet apparatus. The lipid extract was then saponified by reflux for $3 \mathrm{~h}$ with a $0.5 \mathrm{~N}$ $\mathrm{KOH}$ solution in methanol. The non-saponifiable lipids were separated by $n$-hexane extraction four times and concentrated using $\mathrm{N}_{2}$ gas. The aliphatic hydrocarbon fraction and the fraction containing fatty alcohols and sterols were isolated from the neutral lipids by silica gel (deactivated with $5 \% \mathrm{H}_{2} \mathrm{O}$ ) column chromatography, using $n$-hexane and a mixture of dichloromethane/methanol (4/ $1, \mathrm{v} / \mathrm{v})$, respectively. The lipids between the two fractions were eluted with $n$-hexane/dichloromethane $(2 / 3, \mathrm{v} / \mathrm{v})$ and discarded. The isolated alcohols and sterols were taken to dryness, redissolved in benzene, and derivatized with $\mathrm{N}$, O-bis(trimethylsilyl)acetamide. For GC analysis, an HP $5890 \mathrm{~A}$ gas chromatograph equipped with a split/splitless injector and a flame ionization detector (FID) was used. An SGE (Australia) OCI-5 cool on-column injector was also fitted in the gas chromatograph for quantification. Separation of aliphatic hydrocarbons was achieved by means of an SPB-1 capillary column ( $30 \mathrm{~m}$ by $0.25-\mathrm{mm}$ internal diameter), and that of alkanols/sterols (as TMS ethers) was accomplished by means of another SPB-1 column of $25 \mathrm{~m}$ by $0.25-\mathrm{mm}$ internal diameter. Oventemperature programming was $45-90{ }^{\circ} \mathrm{C}$ at $15{ }^{\circ} \mathrm{C} \mathrm{min}-1$ and $90-270{ }^{\circ} \mathrm{C}$ at $3{ }^{\circ} \mathrm{C} \mathrm{min}^{-1}$ for analyses of aliphatic hydrocarbons, and $45-90{ }^{\circ} \mathrm{C}$ at $15{ }^{\circ} \mathrm{C} \mathrm{min}^{-1}$ and 90 $250{ }^{\circ} \mathrm{C}$ at $3{ }^{\circ} \mathrm{C} \min ^{-1}, 30 \mathrm{~min}$ at $250{ }^{\circ} \mathrm{C}$ for analyses of alkanols/sterols. Identification was made with co-injection of authentic standards and GC-MS. Based on replicate analyses, the analytical precision of lipids was calculated to be $2-8 \%$. The gas chromatography-mass spectrometry (GC-MS) analyses were performed with an HP 6890 GC (HP-1MS cross-linked methyl siloxane column, $30 \mathrm{~m}$ by $0.25-\mathrm{mm}$ internal diameter) interfaced directly to an HP 5973 quadruple mass selective detector (electron impact, electron energy $70 \mathrm{eV}$, scanned from 50 to 550 daltons).

\section{Results and discussion}

Five TSM samples collected during normal flow (on 6 and 29 April 2000) exhibit similar distribution patterns for aliphatic hydrocarbons. The aliphatic hydrocarbon distribution (Fig. 2), similar to that of weathered fossil fuels, is extremely complex with a large signal of unresolved complex mixture (UCM) which is usually considered indicative of petroleum contamination or biodegradation (Brassell and Eglinton 1980). Resolved $n$-alkanes are predominantly in the lower molecular-weight range $\left(<\mathrm{C}_{23}\right)$, and higher molecular-weight $n$-alkanes account only for a small proportion. Furthermore, mass chromatograms of characteristic ions m/e 85, 191 and 217 illustrate the distribution of alkanes, triterpanes, and steranes, respectively (Fig. 3). For pentacyclic triterpanes (m/e 191), both $17 \alpha(\mathrm{H}), 21 \beta(\mathrm{H})$-30-norhopane ( $\mathrm{C}_{29}$ hopane) and $17 \alpha(\mathrm{H}), 21 \beta(\mathrm{H})$-hopane ( $\mathrm{C}_{30}$ hopane), which are imprints of petrogenic contamination (Albaiges and Albrecht 1979), were found. However, sterane (m/e 217) characteristic ions are of very low intensity, and no steranes were found. These results indicate that the TSM samples collected during normal flow contain predominantly old hydrocarbon components. However, the whole Lanyang River is, to the authors' knowledge, in an area without any operations 

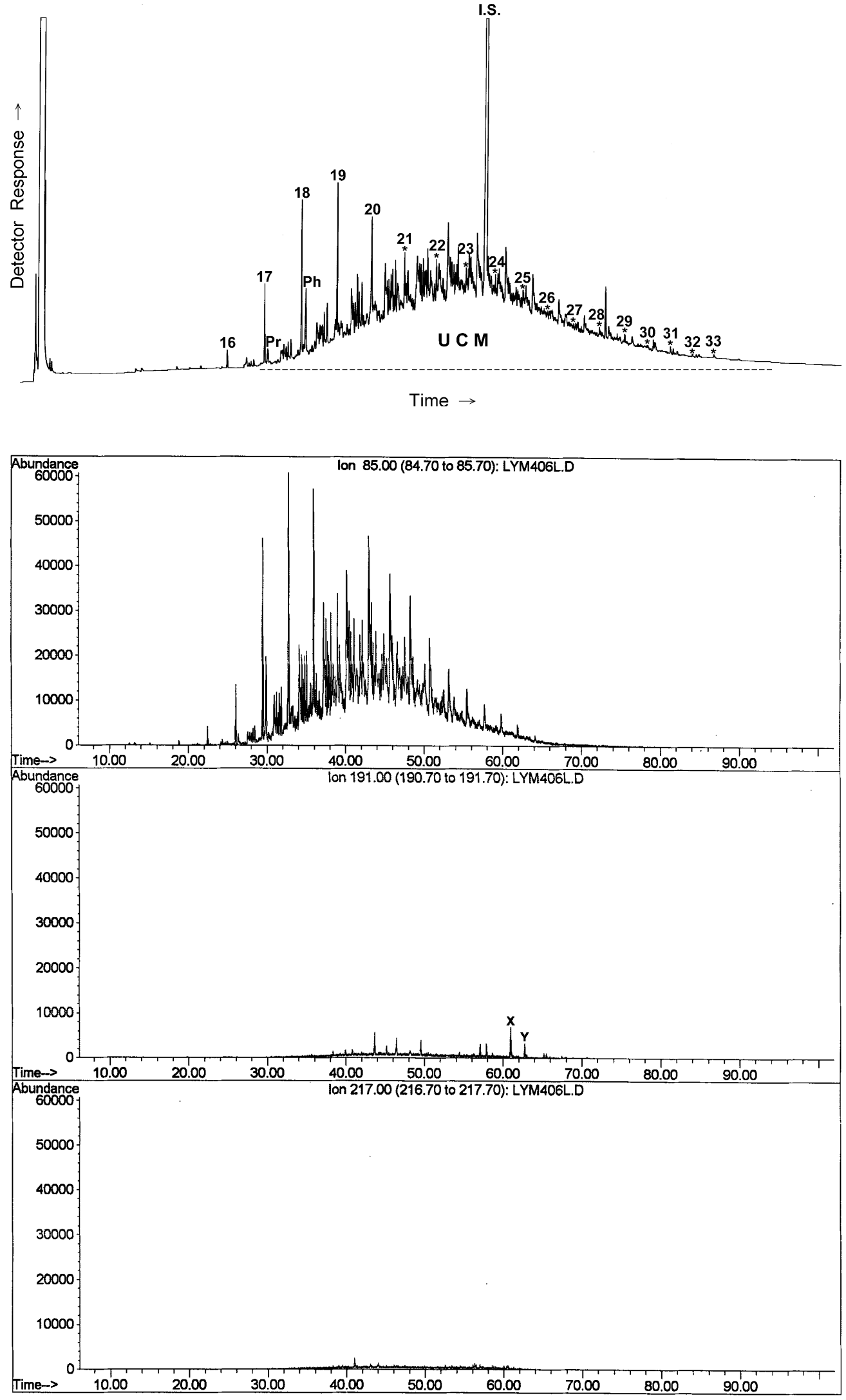

Fig. 2

Gas chromatogram of the aliphatic hydrocarbon fraction from station 8 (sampling on 6 April 2000) during normal flow periods. Numbers above peaks refer to carbon numbers of $n$-alkanes. $P r$ Pristane, $P h$ phytane, I.S. internal standard $\left(n-\mathrm{C}_{24} \mathrm{D}_{50}\right), U C M$ unresolved complex mixture
Fig. 3

Specific ion plots for $\mathrm{m} / \mathrm{e} 85$ (alkanes), 191 (triterpanes), and 217 (steranes) from the GC-MS analysis of the aliphatic hydrocarbon fraction from station 5 (sampling on 6 April 2000). In the plot of the m/e 191 ion, $X$ indicates $17 \alpha(\mathrm{H}), 21 \beta(\mathrm{H})$-30-norhopane $\left(\mathrm{C}_{29}\right.$ hopane), and $Y$ indicates $17 \alpha(\mathrm{H}), 21 \beta(\mathrm{H})$-hopane ( $\mathrm{C}_{30}$ hopane) related to oil industry, oil spill, etc. The present result definitely can not be attributed to anthropogenic oil pollution.
Along the main channel, a narrow road was broadened to a two-lane highway and then paved in 1959. Many roads were built during the period 1975-1980 (Anon 1974, 1983). 


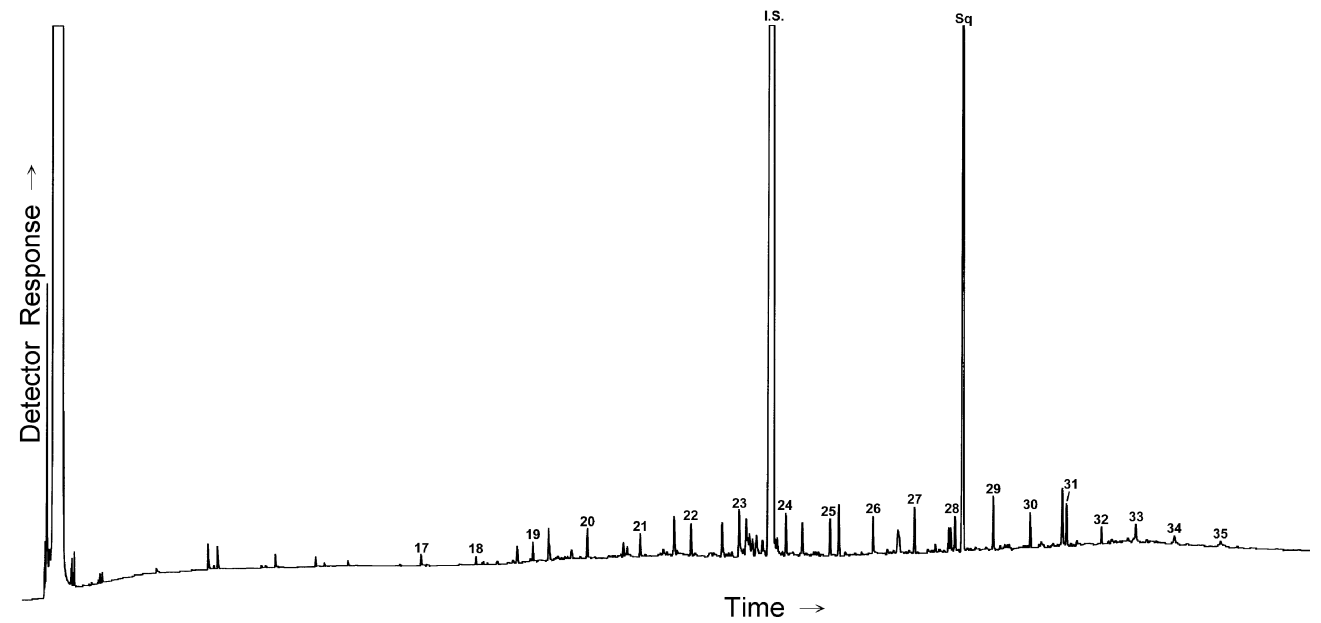

Fig. 4

Gas chromatogram of the aliphatic hydrocarbon fraction from station 1 (sampling on 13 October 1998) during high flow periods. Numbers above peaks refer to carbon numbers of $n$-alkanes. I.S. Internal standard $\left(n-\mathrm{C}_{24} \mathrm{D}_{50}\right)$, $S q$ squalene
Vegetable farms were probably expanded during this period, too. The coastal highway was broadened in 1979 to export farm produce and sand for construction on other parts of the island. As a result, before 1976 the sediment yield fluctuated from 100 to $9,000 \mathrm{~g} \mathrm{~m}^{-2}$ year $^{-1}$ whereas after 1976, the values varied between 2,500 and $21,300 \mathrm{~g} \mathrm{~m}^{-2}$ year $^{-1}$ (Kao and Liu 1996). This increase in sediment yield evidently reflects increased mixing of old hydrocarbons derived from bedrock lipids with modern hydrocarbons from the biota.

Three TSM samples collected during high flow (13 October 1998) showed quite different aliphatic hydrocarbon patterns than those of normal flow. Because of high flow, suspended sediment concentrations are one to two orders of magnitude higher than those of normal flow. For example, values recorded on 13 October 1998 at stations 1, 2, and 8 are 3.49, 4.56 , and $8.20 \mathrm{~g} \mathrm{l}^{-1}$, respectively, those for stations 5 and 8 on 6 April 2000 are 0.066 and $0.018 \mathrm{~g} \mathrm{l}^{-1}$, respectively, and those for stations $1,5,8$, and 9 on 29 April 2000 are 0.267, $0.067,0.053$, and $0.013 \mathrm{~g} \mathrm{l}^{-1}$, respectively. A representative gas chromatogram of aliphatic hydrocarbons for the three samples collected during high flow is given in Fig. 4. Compared with normal flow (Fig. 2), the aliphatic hydrocarbon distribution in TSM at high flow is relatively simple - a minimal UCM, and the dominant components being $n$-alkanes (Fig. 4). One explanation for this difference in UCM could be the dilution of old hydrocarbons by larger particles at high suspended sediment concentration. This is based on the result of a much larger quantity of UCM in the clay than in the silt and sand fractions (Brassell and Eglinton 1980). Another possible cause for the difference is that much of the fine suspended sediment in the river had already been 'purged' to a low level by high daily discharges for more than two weeks before sampling. For instance, from the passing of typhoon Yanni (27-29 September 1998) to the sampling date (13 October), daily mean discharges ranged between 106 and $1,220 \mathrm{~m}^{3} \mathrm{~s}^{-1}$, with an average of $371 \mathrm{~m}^{3} \mathrm{~s}^{-1}$. Extremely high suspended sediment loads $\left(1.5-3.3 \times 10^{6}\right.$ metric tonnes per day) were recorded for 28 September (river-flow gauging station near sampling station 8; Water Resources Bureau 1999).

With respect to the contribution of higher plant waxes, they are mostly shadowed by the old hydrocarbons in the low-flow period (Fig. 2) but are clearly seen in the highflow period (Fig. 4). There is a slight odd/even predominance in the $\mathrm{C}_{25}$ to $\mathrm{C}_{33} n$-alkane range, indicating a relatively small contribution from vascular plants $\left(n-\mathrm{C}_{25}\right.$, $n-\mathrm{C}_{27}, n-\mathrm{C}_{29}, n-\mathrm{C}_{31}$ and $n-\mathrm{C}_{33}$ ) to the TSM (Eglinton and Hamilton 1967; Rieley and others 1991). Also, a small contribution from algae (such as $n-\mathrm{C}_{17}$; Blumer and others 1971) to the TSM is noted. Terrestrial higher plant wax contribution to sediment or soil is generally expressed by the carbon preference index (CPI) of $n$-alkanes. Higher CPI values indicate higher contribution from vascular plants; ancient sediment and fossil fuels tend to have CPI values of around 1 . The CPI values for eight TSM samples range from 1.14 to 2.35 (Table 1), with an average of 1.62. Station 9 is in an adjacent watershed in the Fushan Experimental Forest, a nature reserve. This station was considered the least-disturbed site and is used as a control station. The CPI value of TSM from station 9 is 5.88. In addition, the average CPI value for seven marine sediments (without being contaminated by fossil fuels) on the immediate slope off northeastern Taiwan is $3.90 \pm 1.05$ (Jeng and Huh 2001). The marine sediments off southwestern Taiwan have been severely polluted with oilrelated pollutants from boats, oil tankers, and petrochemical wastes, and exhibit low CPI values ranging from 1.3 to 4.4 , with a mean of 1.8 (Jeng 1986). Most CPI values of the TSM are not much greater than 1 and are considered to be comparatively low, revealing that there is a small contribution of $n$-alkanes from higher plants or a large contribution from old hydrocarbon sources. One may ask what is the percentage of old hydrocarbons in the TSM? The answer is about $87 \%$, based on the average CPI of 1.62 for the TSM, and assuming the CPI of old $n$-alkanes is 1 and that of modern $n$-alkanes is 5.88 (control station). As shown in Fig. 5 and Table 2, even-carbon $n$-alkanols dominate over odd-carbon ones, and $\mathrm{C}_{22} n$-alkanol greatly outweighs other $n$-alkanols. An earlier study by Eglinton and Hamilton (1967), and later studies by Prasad and others (1990), Rieley and others (1991), and Vioque and others (1994) indicate that $\mathrm{C}_{24}, \mathrm{C}_{26}$, and $\mathrm{C}_{28} n$-alkanols are the most abundant components of higher plants, and that $\mathrm{C}_{22} n$-alkanol is only a minor one. Similarly, some local land plants also exhibit the same $n$-alkanol distribution 
Table 1

Aliphatic hydrocarbons in total suspended matter from the Lanyang River

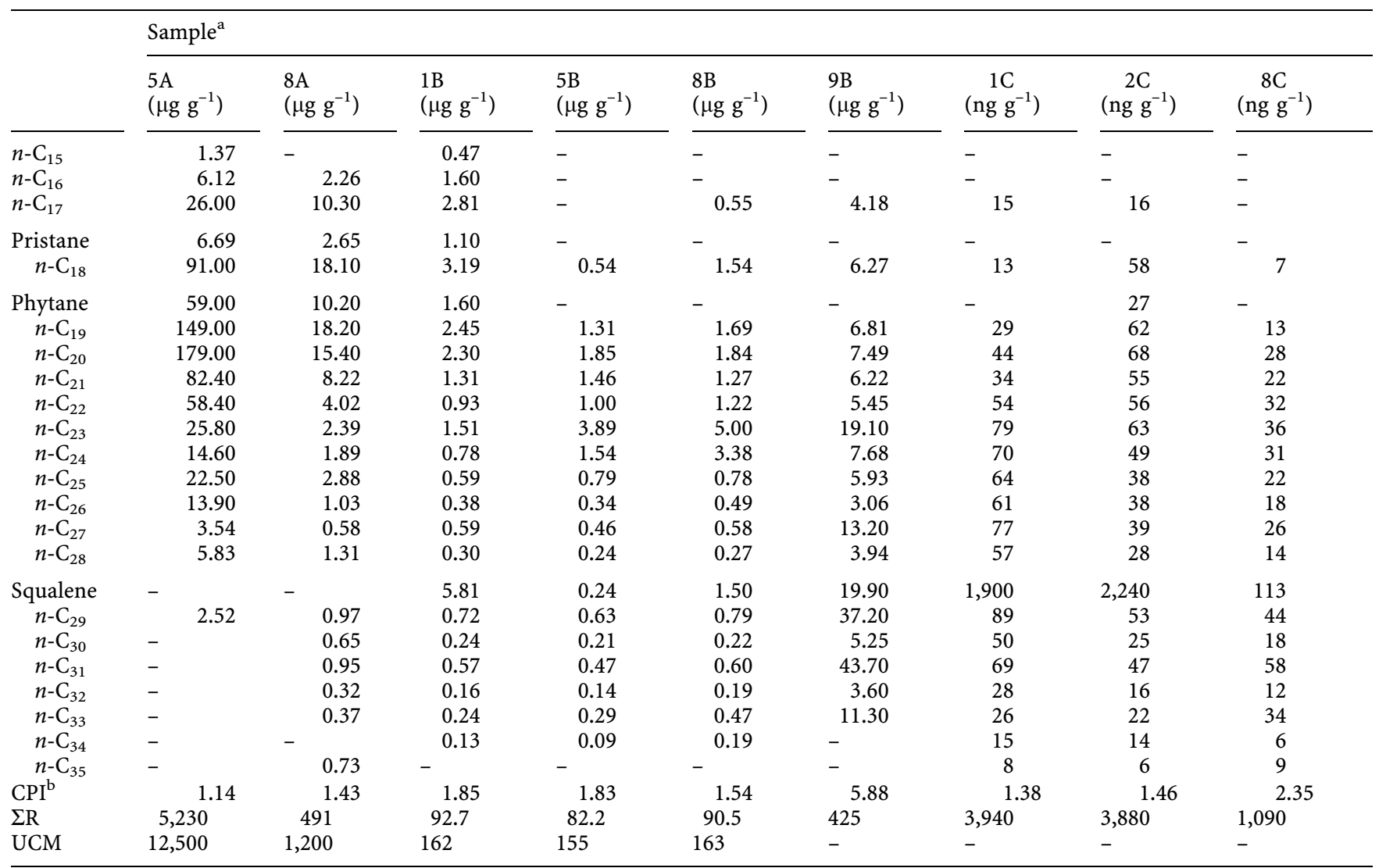

${ }^{\text {a }}$ Sample code: numbers denote sampling stations; letters denote sampling dates; A, 6 April 2000; B, 29 April 2000; C, 13 October 1998

${ }^{\mathrm{b}} \mathrm{CPI}=$ carbon preference index $=\frac{1}{2}\left(\frac{n \mathrm{C}_{25}+n \mathrm{C}_{27}+n \mathrm{C}_{29}+n \mathrm{C}_{31}+n \mathrm{C}_{33}}{n \mathrm{C}_{24}+n \mathrm{C}_{26}+n \mathrm{C}_{28}+n \mathrm{C}_{30}+n \mathrm{C}_{32}}+\frac{n \mathrm{C}_{25}+n \mathrm{C}_{27}+n \mathrm{C}_{29}+n \mathrm{C}_{31}+n \mathrm{C}_{33}}{n \mathrm{C}_{26}+n \mathrm{C}_{28}+n \mathrm{C}_{30}+n \mathrm{C}_{32}+n \mathrm{C}_{34}}\right)$

${ }^{\mathrm{c}} \Sigma \mathrm{R}=$ total resolved aliphatic hydrocarbons

${ }^{\mathrm{d}} \mathrm{UCM}=$ unresolved complex mixture

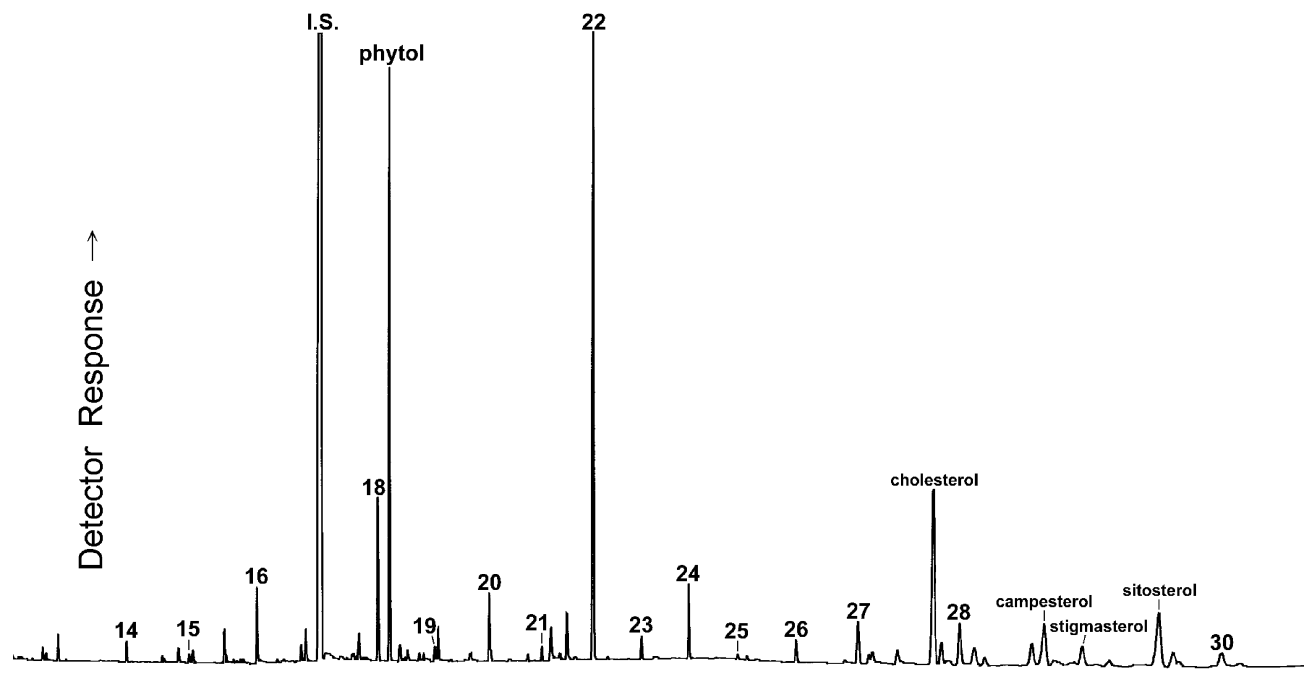

Time $\rightarrow$
Fig. 5

Gas chromatogram of the alka$\mathrm{nol} /$ sterol fraction from station 8 (sampling on 6 April 2000). Numbers above peaks refer to carbon numbers of $n$-alkanols. I.S. Internal standard $\left(n-\mathrm{C}_{17} \mathrm{OH}\right)$

pattern. Thus, higher plants obviously are not the major showing a strong predominance of $\mathrm{C}_{22}$ and $\mathrm{C}_{26: 1}$, but it is source of $\mathrm{C}_{22} n$-alkanol in the river suspended matter. On unlikely that these algae are the major contributor (such the other hand, Volkman and others (1998) report that as algal blooms) of the river suspended matter. What then some freshwater algae contain $n$-alkanols from $\mathrm{C}_{16}$ to $\mathrm{C}_{28}$, is the source of the $\mathrm{C}_{22} n$-alkanol maximum observed in 
Table 2

Alkanols and major sterols in total suspended matter from the Lanyang River (i.s. internal standard)

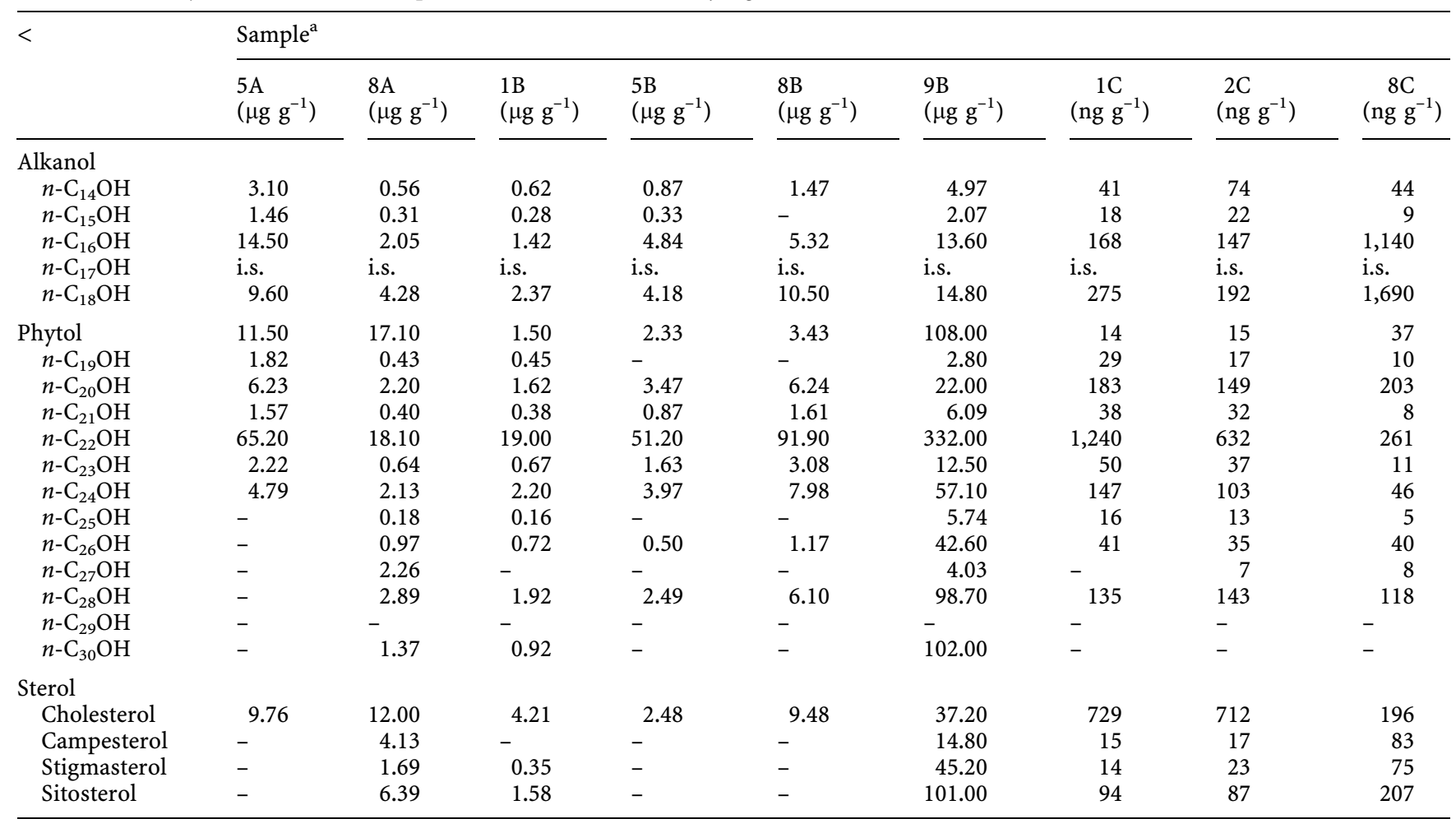

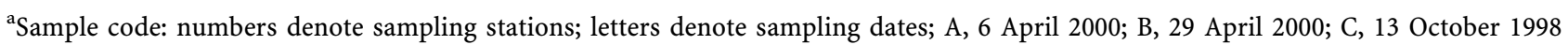

the river suspended matter? A more likely contributor would be decomposer organisms, which have been suggested as the source of $C_{22} n$-alkanol (Cranwell 1981) and inferred by some researchers for a sedimentary $\mathrm{C}_{22} n$ alkanol maximum (Keswani and others 1984; ten Haven and Rullkötter 1991). The presence of a $\mathrm{C}_{22} n$-alkanol maximum in the TSM can reasonably be attributed to a major contribution from bacteria.

It is seen from Fig. 5 that cholesterol (cholest-5-en-3 $\beta$-ol), campesterol (24-methylcholest-5-en-3 $\beta$-ol), stigmasterol (24-ethylcholesta-5,22E-dien-3 $\beta$-ol), and sitosterol (24ethylcholest-5-en-3 $\beta$-ol) are the four dominant sterols found in the TSM samples, and their concentrations are listed in Table 2. Cholesterol is quantitatively the most important sterol in animals (Tissot and Welte 1978) and is widespread in plant life (Volkman 1986). It and other minor sterols often accompany the major sterols of higher plants (Weete 1976). Three phytosterol - campesterol, stigmasterol, and sitosterol - are generally found in epicuticular waxes of vascular plants (Scheuer 1973; Weete 1976), although they can also be produced by marine algae (Volkman 1986). The present result appears to indicate that higher plants are the predominant sterol sources for TSM.

\section{Conclusions}

The CPI values of $n$-alkanes $\left(\mathrm{C}_{25}-\mathrm{C}_{33}\right)$ for eight TSM samples from the Lanyang River range from 1.14 to 2.35 (average
1.62), which are considered relatively low when compared with the control station $(\mathrm{CPI}=5.88)$ and other areas surrounding Taiwan. The low CPI values suggest a high proportion (ca. 87\%) of old hydrocarbons in the TSM; this is not from oil contamination but is derived from the argillite of bedrock due to anthropogenic disturbance. In addition, the source of the $\mathrm{C}_{22} n$-alkanol maximum in the alkanol fraction is thought to be mainly from bacteria, not from plants.

Acknowledgements This study was supported by the National Science Council (ROC) grant NSC89-2611-M-002-044. Our thanks go to an anonymous reviewer for helpful comments on the manuscript.

\section{References}

Albaiges J, Albrecht P (1979) Fingerprinting marine pollutant hydrocarbons by computerized gas chromatography-mass spectrometry. Int J Environ Anal Chem 6:171-190

Anonymous (1974) Statistical abstract of transportation and communications 1974, Republic of China. Ministry of Communications, Taipei, Taiwan, Republic of China

Anonymous (1983) Statistical abstract of transportation and communications 1983, Republic of China. Ministry of Communications, Taipei, Taiwan, Republic of China

Blumer M, Guillard RRL, Chase T (1971) Hydrocarbons of marine plankton. Mar Biol 8:183-189

Brassell SC, Eglinton G (1980) Environmental chemistry - An interdisciplinary subject. Natural and pollutant organic compounds in contemporary aquatic environments. In: Albaiges J 
(ed) Analytical techniques in environmental chemistry. Pergamon, Oxford, pp 1-22

Chang JC (1997) Distribution, morphology and geomorphic implication of the alluvial fans in Taiwan. Ti-Chih ROC 17:69-93 Cranwell PA (1981) Diagenesis of free and bound lipids in terrestrial detritus deposited in a lacustrine sediment. Org Geochem 3:79-89

Eglinton G, Hamilton RJ (1967) Leaf epicuticular waxes. Nature 156:1322-1335

Ho CS (1975) An introduction to the geology of Taiwan. Ministry of Economic Affairs, Taipei, Taiwan, Republic of China

Ho CS (1982) Tectonic evolution of Taiwan. Ministry of Economic Affairs, Taipei, Taiwan, Republic of China

Hung TC, Chuang A, Wu SJ, Tsai CCH (1990) Relationship among the species and forms of copper and biomass along the Erhjin Chi coastal water. Acta Oceanogr Taiwanica 25:65-76

Jeng WL (1986) Hydrocarbons in marine sediments off southwestern Taiwan. Proc Natl Sci Counc ROC (A)10(2):123-129

Jeng WL, Han BC (1994) Sedimentary coprostanol in Kaohsiung Harbour and the Tanshui Estuary, Taiwan. Mar Pollut Bull 28:494-499

Jeng WL, Huh CA (2001) Comparative study of sterols in shelf and slope sediments off northeastern Taiwan. Appl Geochem 16:95-108

Kao SJ, Liu KK (1996) Particulate organic carbon export from a subtropical mountainous river (Lanyang Hsi) in Taiwan. Limnol Oceanogr 41:1749-1757

Keswani SR, Dunham KW, Meyers PA (1984) Organic geochemistry of late Cenozoic sediments from the subtropical South Atlantic Ocean. Mar Geol 61:25-42
Li YH (1976) Denudation of Taiwan Island since the Pliocene epoch. J Geol 4:105-107

Prasad RBN, Müller E, Gülz P-G (1990) Epicuticular waxes from leaves of Quercus robur. Phytochemistry 29:2101-2103

Rieley G, Collier RJ, Jones DM, Eglinton G (1991) The biogeochemistry of Ellesmere Lake, U.K. I. Source correlation of leaf wax inputs to the sedimentary lipid record. Org Geochem 17:901-912

Scheuer PJ (1973) Chemistry of marine natural products. Academic Press, New York, pp 58-87

ten Haven HL, Rullkötter J (1991) Preliminary lipid analyses of sediments recovered during leg 117. In: Prell WL, Niitsuma N (eds) Proc Ocean Drilling Program. College Station, TX, Sci Res 117:561-569

Tissot BP, Welte DH (1978) Petroleum formation and occurrence. Springer, Berlin Heidelberg New York

Vioque J, Pastor J, Vioque E (1994) Leaf wax alcohols in Coincya (Brassicaceae). J Am Official Chem Soc 71:671-673

Volkman JK (1986) A review of sterol markers for marine and terrigenous organic matter. Org Geochem 9:83-99

Volkman JK, Barrett SM, Blackburn SI, Mansour MP, Sikes EL, Gelin F (1998) Microalgal biomarkers: A review of recent research development. Org Geochem 29:1163-1179

Water Resources Bureau (1999) Hydrological yearbook of Taiwan, Republic of China 1998. Ministry of Economic Affairs, Taipei, Taiwan, Republic of China

Weete JD (1976) Algal and fungal waxes. In: Kolattukudy PE (ed) Chemistry and biochemistry of natural waxes. Elsevier, Amsterdam, pp 349-418 